\title{
Discussing publicness on the public square?
}

\author{
Veldsman, Danie \\ University of Pretoria \\ danie.veldsman@up.ac.za
}

\begin{abstract}
In the wide-ranging and multifaceted discourses of public theologies within very different and pluralistic contexts, the strongest contemporary emphasis falls on their integrity and relevance in relating to their respective contexts and socio-political movements within those much globalised contexts. This emphasis is questioned, arguing that a more fundamental and critical question is at stake. Against the background of a short overview of different stories (self-understandings) of public theology, the critical question is put forward, namely whether the emphasis should fall on the public square after all, but much rather on the 'publicness' of rationality that precedes the different contexts (squares!). The focus is therefore on the publicness of rationality in pursuit of the old well-known but ever challenging question, namely 'will the real public theology please stand up'. It is argued that the integrity and relevance that 'public theologies' strive for, are to be firstly sought and found in their models of rationality - as the 'stuff' of embodiment as sites of struggle and survival that they are woven from - and secondly contextually articulated and explicated in engagement and conversation with the very pluralism they hope to address in a constructive-realistic manner.
\end{abstract}

Key words

Publicness; public square; contexts; public theology

\section{Introduction}

If the question should be asked today: Shall the real public theologians please stand up. I can imagine from my readings of the wide-ranging and multi-faceted discourses of and on public theologies in North, South and Asian contexts that the responses will be rather chaotic and deeply divisive. Some theologians will immediately stand up affirmatively without any hesitation. Some will - in loud protest - remain seated. Some will simply 
ignore the question, turning a deaf ear and blind eye. And others will rise slowly whilst engaging in heavy debates whether they should stand or remain seated. The point is: There is a very broad and confusing spectrum of views and an even wider range of dimensions that find expression in the contemporary public-theological discourses.

Whereas for many, public theology is the "Christian engagement and dialogue within the church and especially with the larger society" (Day \& Kim 2017:14) and then with a very specific objective, namely to seek "the welfare of the state and a fair society for all by engaging issues of common interest" (Day \& Kim 2017:14). For others - as is stated on the Website of 'Public Theology Reimagined' - it is about 'the virtues that accompany the work of theology, not just the ideas". For them it entails "connecting grand religious ideas with messy human reality" (Public 2017:1).

This connecting of ideas with reality comprises the articulation of "religious and spiritual points of view' with a very specific objective, namely "to challenge and deepen thinking on every side of every important question' (Public 2017:1). For both the precious outcome of engagement, and taking on the societal challenges, lies in explicating the "Christian position in a way that can be publicly understood and thereby open to public debate and critical enquiry" (Forrester 2004:6).

For others again, public theology - as interestingly expressed by the South African theologian Andries van Aarde (2008: 1214) - is "not about theologians or pastors 'doing theology' in the public square". For him, the public theologians (as seekers) 'are the film directors, artists, novelists, poets, and philosophers' and public theology (done by the 'strangers')" and seen "as the inarticulate longing of believers who do not want to belong" (Van Aarde 2008:1217).

I find the debate on the 'who' of public theologians and the 'what' of public theology very fascinating and enriching for our theological discourses and for the seeking of theological identities. However, I would like to address the issue on public theology from yet another angle. Whether we are seekers or strangers (as Van Aarde almost poetically phrases his explication), or whatever sense-making discourses and manners we all engage in, we all contextually belong to specific epistemic communities. From our very situatedness as epistemic communities, we all speak and 
reflect in our pluralistic contexts (and often intense sites of struggle) on our understandings of the meanings of life and religiosity. My limited focus as critical question will only be on how we go about our conversations, that is, on - what I will call - the 'publicness of rationality' and discernment.

In addressing the 'publicness of rationality', I will be covering three points, namely:

- A few general remarks to give an indication 'Where I am speaking from' (to repeat the well-known phrase of the French philosopher Paul Ricoeur to his student; see Kearney 2010:xi);

- Relating where I am speaking from to a few broad remarks on the self-understandings of the current public theological discourses;

- From the self-understandings to motivate my specific viewpoint on the 'publicness of rationality' and discernment.

My indication 'from where am I speaking' will be embedded within another question, namely: What is missing?

\section{Missing?}

As was indicated in my introduction to discourses on 'Public Theology' and 'Public Theologians', these are terms that are utilised in many different ways with very different meanings. With this in mind, I would like to join the current discourses with a question, simply phrased: Missing?? The phrasing of my question comes from a recent publication on Public Theology. Let me explain.

The title of Part 1 of the publication Contextuality and Intercontextuality in Public Theology (2013) of the Bamberg Conference (Germany) that was held in 2011, reads: Part 1: Intercontextuality - Searching for Public Theology.

My first reaction was: Has it gone missing? This was precisely my reaction many years ago as student as I was driving through a suburb in Pretoria, South Africa on my way to the university when I saw the message on an electronic billboard that was put up in front of the church to indicate the themes for their sermons that Sunday. The theme for the morning sermon was: Jesus walks on the water. For the evening sermon, it read: In search of Jesus. What indeed - that was my own inner enjoyment of the reading of the 
themes - happened then between the morning and evening sermon with Jesus? It was surely not the intention of whoever formulated the themes, to create such a 'misplaced' critical question on Jesus being 'missing'. I find however there 'misplacement' very appropriate for posing my critical question to this publication on Public Theology and specifically Part 1: What precisely has gone missing - and even worse, has gone missing in public? That it should 'go missing' is precisely what should happen. This very unclear and confusing statement necessitates explanation. I would like to utilise as explanatory vantage point a few and very broad theological remarks from two Protestant scholars and a well-known declaration to make my remark on 'missing' clear.

The Dutch neo-Calvinist theologian Abraham Kuyper (1837-1920) wrote:

If God is sovereign, then his lordship must extend over all of life, and it cannot be restricted to the walls of the church.

And:

There is not a square inch in the whole domain of our human existence over which Christ does not cry: 'Mine!' (cf Bratt 1998:488).

One more reference must suffice. It a reference from the German context:

In the powerful formulation of the second thesis of the Barmen Declaration of the Confessing Church (1934), it is stated that God lays claim upon our whole life and that there should be no - yes, no areas of life in which we would not belong to Jesus Christ. The German theologian Bonhoeffer shared the very same conviction in his own way of stating the following regarding the reality of God which is - according to Bonhoeffer - disclosed only as it places me in the reality of the world. And he adds: There is no part of the world no matter how lost no matter how godless that has not been accepted by God in Jesus Christ and reconciled by God (cf Bedford-Strohm 2013:6,8).

Let me continue and go further by adding to these Dutch and German references a contextual remark on 'Where I am speaking from?' 


\section{Where am I speaking from?}

I am speaking from a South African context. A context that is highly politicised. A society that gives the strong impression that its peoples are mostly and strongly religiously orientated. Within the society there are many divisions - be it culturally, economically, socially - and very vulnerable groupings for various reasons whether because of classism, racism, poverty, criminality, corruption - too many to list them all. In reference to theological reflection within such a scarred society and from different sites of struggle, the (former) systematic theologian and now Director of the Business School of the Stellenbosch University, Piet Naudé (2016:220) writes:

Whereas theologies of all convictions during the apartheid era were 'public' in the general sense of dealing with public - mostly political - issues, post-apartheid theologies had to learn a different discourse. They had to become public theologies in the narrower, more specific sense, namely public theology understood as a normative concept, designating an ideal that developed together with typically Western democratic culture', where theology, theologians and the church are but one set of players affecting public life with no assumed or 'natural' influence. Public theology in this sense 'refers to a specific sphere of human life together distinct from politics, the economy and civil life, namely a deliberate formation of public opinion which has the common good at heart and promotes human dignity and justice'

Naudé (2016:221) subsequently identifies two fundamental challenges for theology. Firstly, the question of methodology, that is, the challenge of a new way of doing theology. Secondly, the question of agenda, that is, the extension of the narrow political agenda by the over inclusion of economics and issues of economic policy in theological reflection. For him, the methodological challenges for post-apartheid theologies finds expression in two themes, namely the defining and profiling of theology as public theology in a narrower, technical sense, and the question of whether prophetic theology would still be the most appropriate mode of discourse to address matters of public concern (including questions related to economic justice). 
Although the South African New Testament scholar Pieter de Villiers closely echoes in his own formulation Naudé's description, he adds another important point in his article The nature of knowledge in the South African theological discourse in the collection of essays on Theology and the (Post) Apartheid Condition (2016). With regard to the nature of knowledge within our society, he states:

The influence of contextual theologies on theology - both locally and internationally - has been extensive. The political activism of contextual theologies, and lately, the development of public theology with its interest in societal engagement have resonated widely with many theologians: one can say with some confidence that the need to account for and address contextuality is now part of mainstream theology. Theology has been made aware of its efficacious and transformative nature. At the same time, churches also have been embracing the need for a theology that relates to society (De Villiers 2016: 40-1)

Subsequently in his exposition De Villiers (2016:41ff) notes the growing disenchantment in and with the theological discourse. It can be seen according to him in a worrying anti-intellectual trend outside theological discourse. According to De Villiers (2016:41), the anti-intellectual trend in reaction to activist theologies "creates the impression that they rather seek to assert power than to serve or inspire'. He continues in reference to a "spiritual need" that needs to be addressed after the "closed, totalitarian rationality that claimed logical argumentation as its highest good" that now - according to him - finds expression in the turn to "spirituality and also in the pursuit of beauty". Insightfully De Villiers (2016:41) describes the motivational dimensions for bringing about the turn as follows: It (that is the turn) "takes place amidst the overpowering effect of the technological age with its overload of information and the consumerist society that dehumanises and pressurises left theologians and faith communities with feelings of frustration and alienation".

Before I address the so called 'after' and the 'turn' that De Villiers alludes to, I would firstly like to engage with an overview which I found to be extremely helpful in making sense of the current diverse and wide-ranging discourses on public theologies (including Naudés perspective on Public 
Theology), namely to the article on 'The Paradigm of Public Theology Origins and Development' by the South African systematic theologian Dirkie Smit from Princeton, USA ${ }^{1}$.

\section{Six contextual stories}

Looking at questions on the origins and development of public theology, Smit (2013:11ff) insightfully argues that it is not a matter that one can easily respond to. His own response is one of telling six contextual stories. $\mathrm{He}$ describes the dominant stories as:

- Theology in the naked public square ${ }^{2}$, that is, theologically informed discourses that are ethical in nature and is available and open to all (cf Smit 2013:13).

- Secondly theology as public discourses, that is the very foundational question on the nature of theology as a discipline, namely what allows theology as such to be a form of public discourse (cf Smit 2013:13-5).

- Thirdly: Theology and the public sphere, that is, an understanding of the church and ethics as actively (constructively and critically) involved in public life (Smit 2013:15-6).

- Fourthly. Theology and Public Struggles, that is, the relationship between faith and public life that found expression on numerous and intense sites of struggle for power and transformation (cf Smit 2013:16-8).

- Fifthly. Theology and Public Life in a Global World, that is, a growing global awareness that takes the complexities of many contexts into account by jointly dreaming a different word (cf Smit 2013:18-9).

- And lastly: Theology and the Public Return of the Religious, that is, the acknowledgement of the public importance of religion since religions and religious convictions play crucial roles in our common world (Smit 2013:19-20).

1 Dirkie Smit has recently been appointed as Rimmer and Ruth De Vries Professor of Reformed Theologies of Mission and Public Life at Princeton Theological Seminary in Princeton, New Jersey, USA.

2 'naked public square' is the result of the separation of religion and political life in America (Smit 2013:12) 
For Smit, there is not the story of Public Theology. There are simply many stories to be told without choosing between them. In his conclusion, however, Smit (2013:20-23) rightfully questions in the light of the six stories that he told, the use of the word 'paradigm', that is, as if public theology in one way or the other can be called a 'paradigm'. He - and for my argumentative purposes very important - turns to the Italian philosopher Giorgio Agamben's essay on 'What is a paradigm?' from which the following important insight comes. Public Theology describes a movement. Doing public theology is simply "moving from one context to the other, learning from their irreducible historicity and particularity" (Smit 2013:23) There is no real public theology that could stand up, no normative discipline of public theology. There are only historical moments of public theology (Smit 2013:23)

With his viewpoint I would like emphatically to agree. However, in my opinion there is a crucial dimension missing that should be added to the 'movements' and 'historical moments'. Is accountability, contextual discernment not our responsibility precisely in those historical moments of movement? And with discernment comes articulation and disclosure. How are we to discern between 'better and worse' engagements, viewpoints, insights, and articulations etc. within historical moments? We cannot simply await the arrival of the owl of Minerva (see Smit 2013:23 where he poses the question). The 'owl'-metaphor is surely applicable to the nature of our knowledge (tentative/incomplete), but not to the contextual discernment of the 'historical moment'. That is: we should be able to say and to be held accountable for that moment - that there are better or worse theological insights, statements or engagements.

Let me give but one influential example before I pursue my own directions of searching for the real public theologies 'to stand up' in the light of the former remarks on contextuality, the nature of knowledge and the six contextual stories. The example I want to mention, is that of Rowan Williams.

The former archbishop of Canterbury Rowan Williams developed during his period of office, "refreshingly and profound views about the role of religion in public life". On the back cover of William's book Faith in the public square, the Roman Catholic priest Timothy Radcliffe, who is the Director of the Las Casas Institute of Blackfriars, Oxford writes: 
Rowan Williams, the finest theologian in Britain, offers in these essays the most penetrating analysis of the moral, cultural and economic crises of our times, and of the role of faith in the public area. It should be read by politicians, economists and artists as well as theologians, and by anyone who cares for the future of our society and planet'.

What does Williams offer?

Williams (2012:1) describes himself in the introductory sentence of his book as "some kind of commentator on the public issues of the day". His book Faith in the Public Square consists of Seven Parts:

1. On ecularism and its discontents;

2. Living with Limits: Liberalism, Pluralism and Law;

3. Living with Limits: The environment

4. Housekeeping: The economic challenge

5. Justice in community

6. Religious diversity and civil agreement

7. Rediscovering religion

Williams treats issues in these seven parts that are of concern for the academy, church and broader society alike: secularism, multiculturalism, religious hatred, the environment, justice, atheism and religious diversity to name but a few. These lectures are according to him "worked examples of trying to find connecting points between various public questions and the fundamental beliefs about creation and salvation from which (I hope) Christians begin in thinking about anything at all" (Williams 2013:2). One finds in these lectures that he is not out to influence public policy directly, nor to proclaim the gospel directly in the public square, but rather indirectly to communicate a vision of Christian faith in corporate life orientated around God. A religious life is a material life in a particular place, a life that takes on "the task of ensuring habitation for God ... (who) is visible only when a human life gives place, offers hospitality to God, so that this place, this identity, becomes a testimony". 
According to Vanhoozer (2015), the book shows 'a still more excellent way' of conceiving and practising public theology. It is radical in that it returns to the etymological roots of the term public. Public theology, as we are using the term, means theology 'made up of people'. God is at work to bring into being a people under his rule in his place. The idea of the people of God, therefore, stands at the heart of biblical theology. The church - not a building - but the people of God, speaking, acting and perhaps suffering - is that 'place' where God and the kingdom of God come into focus. And as regards their very speaking, acting and perhaps suffering as witness, Williams does indeed ask of us on the public square to pose the question of truth, that is, a question that indeed requires conversation on discernment and contextual discernment, and requires 'ways of addressing' the truth. That is the precisely the point that all 'public theological' movements cannot avoid or push aside. That is what I would like to call in my critical engagement viewpoints on 'public theology' and 'public theologians': Discernment as missing in our contexts.

\section{Missing in contexts of discernment}

' $(\mathrm{W})$ hat is rational to believe or do is relative to a particular situation should ... not be confused with the thesis that rationality itself is relative' (Van Huyssteen 1998:32)

Theology is made up of people, that is, theological reflection as an activity of a community of enquirers that take place within the spaces of our communicative practices and the dynamics of our lifeworld involvements. As communities, situated in concrete and specific social-cultural historical context, we have to acknowledge from contemporary hermeneutical discourses and insights that we engage with our contexts from a vantage point of interpreted experiences. Our quests and discernments for intelligibility and ultimate meaning within our life worlds and/or on our sites of struggle, are (rational) activities shaped by rational agents and epistemic values. In these very activities, we share - and we should - common resources of rationality, that is, cognitive, evaluative and pragmatic resources. It is in this sense that we all - without any choice - are and should be public theologians. We do not have any privileged Gardenof-Eden epistemological positions that we can engage from with our 
contexts. Put differently: The 'stuff' that discernment - and subsequently our articulations and disclosures - are made off, are public: This is the point that I have been working towards in my argument. In our very pluralistic contexts and often intense sites of struggle in which we do our theological reflection and make theological statements, we will unavoidably have to start our conversations by bringing our views, convictions, and judgements to those with who we are sharing immediate and also different life worlds. In philosophical terms: With those that make up our epistemic communities.

In the above, I closely follow the so called post foundational perspective on rationality of the South African theologian Wentzel van Huyssteen (1998:32 1999:179ff). His perspective makes sense to me and is convincing, namely that the epistemic movement in a post foundational evaluation of opinions and viewpoints goes from individual judgement to expert evaluation to intersubjective conversation. Because each judgement always takes place in some community, and each community has a particular history, the broader research tradition(s) in which communities are embedded will epistemically shape but not completely determine the questions one asks, the assumptions one makes, and the arguments one finds persuasive (cf Van Huyssteen 1998:32). For Van Huyssteen, religion and religious experiences are but products of human rationality. And to me, this is just another way of acknowledging the publicness of sense making of our ultimate concerns within our own contexts - that which we call our public squares. On these squares, our discernments cry out for accountability, or perhaps better formulated from discourses on rationality: for responsible justification and substantiation of our values and beliefs.

\section{Conclusion}

Searching for Public Theology was the starting point of my argument. I said that it had to go 'missing'. What has to go missing (in the sense of consciously putting aside) is an understanding of faith and rationality that is locked inside the modernist dilemma of privatized, subjective religious beliefs over against/opposed to a superior, universal rationality on the public square (of which the natural sciences are the best example). Since the whole of creation and of existence - as mentioned in the introduction - belongs to the Lord, we cannot treat our other beliefs within the public 
square differently from the network of beliefs in which we have and hold our religious experiences (cf Van Huyssteen 1999:197ff). Our search from understandings of religious experiences, religion and the values we are holding for dear, are products of human rationality and should not be isolated from the public domain. It should find itself as part and parcel of cross-contextual, interdisciplinary conversations within the public domain. If we then rightly with De Villiers criticises within our South African contexts the unacceptable heritage of a 'totalitarian rationality', then I cannot immediately and fully agree with his subsequent choice for a shortcut turn to 'spirituality' and 'aesthetics'. Nor can I agree with Naudé that the biggest challenge for public theology comes from methodological challenges, and then in the sense firstly of defining and profiling of theology as public theology in a narrower, technical sense, and secondly the question of whether prophetic theology would still be the most appropriate mode of discourse to address matters of public concern. Both challenges in my opinion are in unavoidably preceded by the question of rationality. Important as both may be, and both should eventually be part of the emerging argument, the missing dimension in his argument is precisely what I will call, the acknowledgement, the recognition of the 'publicness of rationality' on the public square, and thus of all theological reflection. We may not bypass it in turning to whatever. We have to go through it. We have to go through it whether we are seekers or strangers. I get the idea that this is what Rowan Williams is propagating in his Faith in the Public Square - although not with my specific emphasis on the publicness of rationality.

It is in this sense that all of us as seekers and strangers should stand up as public theologians, acknowledging religion and religious experience as products of rationality, and held accountable as we are moving from one context to another, from one site of struggle to another, where and how we make theological statements and hold our values - freed from the modernist dilemma - on our respective (contextual) public squares. 


\section{Bibliograhy}

Bedford-Strohm, Heinrich; Hoëhne, Florian and Reitmeier, Tobias (eds) 2013. Contextuality and Intercontextuality in Public Theology. LIT Verlag: Berlin

Bratt, James D (ed) 1998. Abraham Kuyper: A Centennial Reader. Grand Rapids: Eerdmans

Day, Katie \& Kim, Sebastian 2017. Introduction, in Kim, Sebastian \& Day, Katie. A Companion to Public Theology. Brill's Companions to Modern Theology. Brill: Leiden, pages 1-21.

De Villiers, Pieter 2016. The nature of knowledge in the South African theological discourse, in Venter, Rian (ed). Theology and the (post) apartheid condition. Sun Media: Bloemfontein, pages 26-49.

Gregersen, Niels and Van Huyssteen, Wentzel (eds) 1998. Rethinking Theology and Science. Six models for the current dialogue. Grand Rapids: Eerdmans.

Hauerwas, Stanley 2013. Review of Rowan Williams's Faith in the Public Square. Theology 116 (2) 119-122.

Kearney, Richard 2010. Anatheism. New York: Colombia University Press.

Kuyper, Abraham 1998. Sphere Sovereignty, in Bratt, James D (ed) Abraham Kuyper: A Centennial Reader. Grand Rapids, MI: Eerdmans.

Naudé, Piet 2016. Pathways in Ethics. Sun Press: Stellenbosch.

Public 2017. Public Theology Reimagined. [Online] Available: https:// onbeing.org/collections/public-theology-reimagined [Accessed 20 Dec 2017]

Smit, Dirk J 2013. The paradigm of public theology - Origins and development, in: Bedford-Strohm, Hoëhne and Reitmeier (eds), page 11-23.

Van Aarde, Andries 2008. What is 'theology' in 'public theology' and what is 'public' about 'public theology'? HTS 64 (3) 1213-1234. 
Van Huyssteen, Wentzel 1998. Postfoundationalism in Theology and Science, in: Gregersen \& Van Huyssteen (eds).

Van Huyssteen, Wentzel 1999. The Shaping of Rationality. Grand Rapids: Eerdmans.

Vanhoozer, Kevin \& Strachan, Owen 2015. The pastor as Public Theologian. Grand Rapids: Baker.

Williams, Rowan 2012. Faith in the Public Square. Bloomsbury: London 